\title{
Effect of Swamp Irrigation Pattern and Sorghum Extract Concentration on Sorghum Seed Sprout
}

\author{
Edi Susilo ${ }^{1 *}$ Nanik Setyowati ${ }^{2}$ Uswatun Nurjannah $^{2}$ Riwandi $^{3}$ Zainal Muktamar $^{3}$ \\ ${ }^{1}$ Student of Doctoral Program for Agricultural Sciences, University of Bengkulu, Bengkulu, Indonesia. \\ ${ }^{2}$ Department of Crop Production, Faculty of Agriculture, University of Bengkulu, Bengkulu, Indonesia. \\ ${ }^{3}$ Department of Soil Science, Faculty of Agriculture, University of Bengkulu, Bengkulu, Indonesia. \\ *Corresponding author.Email: susilo_agr@yahoo.com
}

\begin{abstract}
Sorghum extract has an allelopathic potential to control weeds. Allelopathy is the suppression of a plant's growth by a toxin released from a nearby plant of the same or another species. One factor determining plants' contribution to releasing allelochemicals is abiotic stress, such as drought. This study aims to determine the efficacy of water extract of sorghum grown in different irrigation patterns cultivated in swamps at various concentrations. This study used a complete randomized block design consisting of two factors. The first factor was the irrigation pattern consisting of saturated water, dry, water-saturated-dry (with interval time one week), dry - water-saturated (with interval time one week), and dry. Sorghum was planted for four weeks in this irrigation pattern. The second factor was the allelopathic concentration, consisted $0 \%, 5 \%, 10 \%, 15 \%, 20 \%$ and $25 \%$. Dry Ultisol soil was used as a control. The research was conducted using the Petri dish bioassay method. The sprout evaluation was carried out on 25 sorghum seeds, which were germinated in each Petri dish. A total of $10 \mathrm{ml}$ of extract from each treatment was added to each Petri dish and then incubated for four days. The experiment results showed that sorghum extract from a plant grown in dry swamplands at a concentration of 5\% to $10 \%$ resulted in the highest sprout inhibition. Therefore, the sorghum extract from dry swamps cultivation has the potential as a bioherbicide.
\end{abstract}

Keywords: swamp, irrigation, extract, sprout.

\section{INTRODUCTION}

Weeds compete with cultivated plants in utilizing resources such as air, air, and the growing environment [1]. Agriculture today is generally oriented towards productivity, with the frequent use of synthetic herbicides and unwise attitude towards the use of synthetic herbicides, causing health problems and environmental pollution. According to [2], synthetic herbicides hurt the environment, needed to control environmentally friendly alternative weeds.

Environmentally friendly alternative weed management is organic weed management and faces challenges in today's crop production systems. At present, weed resistance to herbicides is a topic of discussion, so that environmentally friendly weed management efforts are needed [3]. Organic weed herbicides. According to [7], low-dose herbicides with water extract of sorghum can be used to control broadleaf weeds in the field. 50-75\% Atlantis 3.6 WG control in plant derivatives is an alternative to dealing with inorganic herbicides [4].

Allelopathy is a type of organic herbicide used to control weeds that are environmentally friendly and sustainable. According to (1), one solution to the problem of weeds' presence in the cultivation environment is to utilize allelopathy. Furthermore, [5] stated that allelochemical compounds and allelopathic plants are strategies to control weeds as natural herbicides. The water extract of sorghum and sunflower plants can reduce weed biomass and increase wheat yields [6].

The contribution of bioherbicides is reducing the dosage of synthetic herbicides, thereby creating environmental safety, human health security, and suppressing weeds that are tolerant of synthetic which is mixed with allelopathic extract of sorghum and sunflower which can increase wheat yield and suppress weeds [6]. 
The application of weed control using allelopathic is an alternative weed management strategy to build an environmentally friendly and sustainable agricultural system. However, the conditions for using the allelopathic must be economical and straightforward. This can be achieved by utilizing locally available allelopathic plants [8]. Sorghum is one of the allelopathic and multi-beneficial plants with wide adaptability.

Sorghum is a photosynthetic, energy-saving, multi-benefit, and potential plant [9]. Sorghum has wide adaptability to various environments and can produce under conditions of limited input [10]. Sorghum can be used as a substitute for other plants that have low economic value [11] so that it can potentially meet the demand for food in the future.

Sorghum is an excellent allelopathic plant. According to [12], sorghum is an allelopathic plant and can inhibit other vegetation so that it can be environmentally friendly weed management. Research related to allelopathy has been carried out from various plant sources. In experiment [13], the aqueous extract concentrations $\left(5.0 ; 10.0 ; 15.0\right.$ g..$\left.^{-1}\right)$ of three different weeds significantly suppressed germination. Sorghum water extract is a bioherbicide that can reduce wet weight, dry weight, and weed density by $31.0 \%, 27.0 \%, 29.0 \%$, respectively, compared to wheat [7].

Through several studies, the role of allelopathy in the field has been shown to affect a. gricultural ecosystems. According to [1], the maize planting conditions after planting sorghum resulted in a lower weed density of $23 \%$ and biomass of $23.6 \%$. In general, the application of multi-system weed control is more optimal than a single system. Furthermore, experiments also carried out by [1] in post-harvest sorghum maize, mulch treatment, and sorghum water extract significantly reduced the presence of weeds. Furthermore, [12], water extract of sorghum inhibited sprout compared to control treatment on cotton plants. Allelopathic has the property of contributing to the cultivation of plants that are environmentally friendly and sustainable. One of the strategies to improve the allelopathic nature with environmental modification, such as giving abiotic stress. According to [5], sources of germplasm such as sorghum can be manipulated in order to improve environmentally friendly weed control.

Current experiments on the relationship between allelopathy and stressful environments have been carried out, but experiments on marginal lands, especially in swamps, have not been carried out. This experiment tries to test the sorghum extract which is the result of cultivation in swampland by applying an irrigation pattern. This study aims to determine the inhibitory ability of water extracts from sorghum plants cultivated in swamplands with different irrigation patterns

\section{MATERIALS AND METHODS}

\subsection{Extract ingredients}

The water extract material of sorghum has undergone treatment, namely dry marshland for four weeks, dry seven days, wet seven days repeated so that twenty-eight days, dry seven days wet seven days repeated so that twenty-eight days, wet for twenty-eight days, and as control, namely dry ultisol soil for twentyeight days. The Numbu variety of sorghum is the main ingredient in the water extract. The shoots and roots of twenty-eight days old sorghum were harvested and dried in the sun for seven days, then dried in an oven at $70,0^{\circ} \mathrm{C}$ for 70 hours. The stems of plants that have been cut 1-2 cm dry and mashed, the resulting powder is used as an air extract material.

\subsection{Prepare aqueous extract}

$100 \mathrm{~g}$ of dry sorghum powder (10\% treatment) soaked in 11 of distilled water and stirred using a shaker for one day and one night. The extract solution was filtered using a cloth and followed by filter paper which was carried out twice. Then the extract is put in a labeled container stored in the refrigerator until the material is using. For concentrations of $10.0 \%$, $15.0 \%, 20.0 \%$, and $25.0 \%$ of this extract was also prepared by the same procedure as above.

\subsection{Bioassay test}

The purpose of this bioassay test is to determine the inhibitory power of sorghum seed sprout growth as a result of water-soluble allelochemical compounds. A petri dish with a diameter of $9.0 \mathrm{~cm}$ is covered with two layers of filter paper. Twenty-five sorghum seeds are planted in each Petri dish, and $10 \mathrm{ml}$ of water extract was added at different concentrations according to the treatment $(5 \%, 10 \%, 15 \%, 20 \%$, and $25 \%$ ) in each of the petri dishes. Furthermore, the sprouts in the petri dish were grown for four days. All sets of experiments were repeated five times.

\subsection{Experimental variable}

Experimental measurements were made at the percentage of normal sprouts capacity (\%), percentage of abnormal sprouts (\%), length of plumule $(\mathrm{cm})$, length of the radicle $(\mathrm{cm})$, wet weight of plumule $(\mathrm{g})$, wet weight of radicle $(\mathrm{g})$, wet weight of cotyledon. $(\mathrm{g})$, cotyledon dry weight $(\mathrm{g})$, root dry weight $(\mathrm{g})$, and plumule dry weight $(\mathrm{g})$. 


\subsection{Statistical analysis}

Randomized block design was used in this experimental design and was repeated six times. Data were analyzed statistically to produce ANOVA and analysis with Duncan's test if significantly different at $\mathrm{P}<0.05$.

\section{RESULT AND DISCUSSION}

The recapitulation of sorghum sprouts variance is shown in Table 1 . The results of the analysis of variance showed that the irrigation pattern treatment had a very significant effect on all observed variables except the wet weight of the radicle. Sorghum extract concentration treatment produced a very significant

Table 1. Recapitulation of the F test of the inhibition of sorghum water

\begin{tabular}{lrrrc}
\hline Variable & $\begin{array}{c}\text { Irrigation } \\
\text { Pattern } \\
(\mathbf{I})\end{array}$ & $\begin{array}{c}\text { Extract } \\
\text { Concentration } \\
(\mathbf{E})\end{array}$ & $\begin{array}{c}\text { Interaction } \\
(\mathbf{I} \text { x E) }\end{array}$ & $\begin{array}{c}\text { Coefficient } \\
\text { of diversity } \\
(\%)\end{array}$ \\
\hline Normal sprout & $10.56 * *$ & $1188.55 * *$ & $11.28 * *$ & 21.54 \\
Abnormal sprout & $39.77 * *$ & $67.52 * *$ & $12.00 * *$ & 15.32 \\
Plumula length & $13.64 * *$ & $2160.78 * *$ & $9.22 * *$ & 14.49 \\
Radicular length & $8.11 * *$ & $2429.96 * *$ & $7.96 * *$ & 18.55 \\
Plumula wet weight & $5.45 * *$ & $1164.58 * *$ & $5.77 * *$ & 18.98 \\
Radicula wet weight & $0.67 \mathrm{tn}$ & $341.01 * *$ & $2.89 * *$ & 0.18 \\
Cotyledon wet weight & $9.29 * *$ & $38.20 * *$ & $2.42 * *$ & 6.92 \\
Plumula dry weight & $14.66 * *$ & $1110.91 * *$ & $7.21 * *$ & 18.15 \\
Radicle dry weight & $16.01 * *$ & $972.03 * *$ & $11.59 * *$ & 24.74 \\
Cotyledon dry & $7.16 * *$ & $192.85 * *$ & & 7.00 \\
weight & & & $1.31 \mathrm{tn}$ & \\
\hline
\end{tabular}

$* *$ = significantly

ns $=$ no significant

effect on all variables. All observed variables were significantly different in the interaction between irrigation pattern and water extract concentration except cotyledon dry weight.

Irrigation pattern model in Ultisol and swampy soils at a concentration of $0.0 \%$ extract in the normal sprouts' variable was higher $(87.0 \%-90.0 \%)$ compared to that of the irrigation pattern with other water extract concentrations shown in Table 2. This shows that the treatment of extract concentrations $0 \%$ produces the highest normal sprouts, this is because there are no allelochemical compounds present in the bioassay test media.

In general, the increasing concentration of the bioassay media extract results in lower normal sprouts. The 5\% extract concentration indicated an inhibition of the normal sprout percentage (20\%$64 \%)$. The inhibition of sorghum extract was achieved by $10 \%-25 \%$, while the proportion of normal sprouts was achieved by $0 \%$. Shows that to produce water extracts with high inhibition, swampland with a dry irrigation pattern (at extract concentrations starting at 5\%) can be the best
Table 2. Interactions between irrigation patterns and water extract concentration of sorghum on germination variables

\begin{tabular}{|c|c|c|c|c|}
\hline Treatment & $\begin{array}{c}\text { Normal } \\
\text { sprout } \\
(\%)\end{array}$ & $\begin{array}{c}\text { Abnormal } \\
\text { sprout } \\
(\%)\end{array}$ & $\begin{array}{c}\text { Plumula } \\
\text { length } \\
(\mathrm{cm})\end{array}$ & $\begin{array}{c}\text { Radicle } \\
\text { length } \\
(\mathrm{cm})\end{array}$ \\
\hline \multicolumn{5}{|l|}{$\begin{array}{l}\text { Irrigation } \\
\text { pattern (I) }\end{array}$} \\
\hline B & $23.17 \mathrm{a}$ & $11.33 \mathrm{c}$ & $2.13 \mathrm{~b}$ & $2.25 \mathrm{~b}$ \\
\hline BK & $25.50 \mathrm{a}$ & $33.17 \mathrm{a}$ & $2.55 \mathrm{a}$ & $2.10 \mathrm{bc}$ \\
\hline $\mathrm{KB}$ & $19.83 \mathrm{~b}$ & $13.00 \mathrm{c}$ & $2.16 \mathrm{~b}$ & $2.10 \mathrm{bc}$ \\
\hline $\mathrm{K}$ & $18.33 \mathrm{~b}$ & $24.17 \mathrm{~b}$ & $2.06 \mathrm{~b}$ & $1.88 \mathrm{c}$ \\
\hline UK & $25.17 \mathrm{a}$ & $39.17 \mathrm{a}$ & $2.59 \mathrm{a}$ & $2.52 \mathrm{a}$ \\
\hline $\begin{array}{l}\text { Prob. F > } 5 \\
\%\end{array}$ & 0.0001 & 0.0001 & 0.0001 & 0.0001 \\
\hline \multicolumn{5}{|c|}{$\begin{array}{l}\text { Extract } \\
\text { concentration }(\mathrm{E})\end{array}$} \\
\hline $0 \%$ & $88.40 \mathrm{a}$ & $4.20 \mathrm{~d}$ & $8.51 \mathrm{a}$ & $11.08 \mathrm{a}$ \\
\hline $5 \%$ & $46.40 \mathrm{a}$ & $40.60 \mathrm{a}$ & $4.30 \mathrm{~b}$ & $1.84 \mathrm{~b}$ \\
\hline $10 \%$ & $0.00 \mathrm{c}$ & $46.80 \mathrm{a}$ & $0.93 \mathrm{c}$ & $0.09 \mathrm{c}$ \\
\hline $15 \%$ & $0.00 \mathrm{c}$ & $27.60 \mathrm{~b}$ & $0.01 \mathrm{~d}$ & $0.00 \mathrm{c}$ \\
\hline $20 \%$ & $0.00 \mathrm{c}$ & $18.80 \mathrm{c}$ & $0.00 \mathrm{~d}$ & $0.00 \mathrm{c}$ \\
\hline $25 \%$ & $0.00 \mathrm{c}$ & $7.00 \mathrm{~d}$ & $0.00 \mathrm{~d}$ & $0.00 \mathrm{c}$ \\
\hline $\begin{array}{l}\text { Prob. F > } 5 \\
\%\end{array}$ & 0.0001 & 0.0001 & 0.0001 & 0.0001 \\
\hline \multicolumn{5}{|l|}{ Interaction } \\
\hline $\mathrm{B} \times 0 \%$ & $87.00 \mathrm{a}$ & $4.0 \mathrm{kl}$ & $8.45 \mathrm{ab}$ & $11.73 \mathrm{a}$ \\
\hline $\mathrm{BK} \times 0 \%$ & $90.00 \mathrm{a}$ & $3.0 \mathrm{kl}$ & $8.40 \mathrm{ab}$ & $9.83 \mathrm{c}$ \\
\hline $\mathrm{KB} \times 0 \%$ & $88.00 \mathrm{a}$ & $4.0 \mathrm{kl}$ & $8.83 \mathrm{a}$ & $10.80 \mathrm{~b}$ \\
\hline $\mathrm{K} \times 0 \%$ & $90.00 \mathrm{a}$ & $4.0 \mathrm{kl}$ & $8.70 \mathrm{a}$ & $11.15 \mathrm{~b}$ \\
\hline UK x $0 \%$ & $87.00 \mathrm{a}$ & $6.0 \mathrm{jkl}$ & $8.15 \mathrm{~b}$ & $11.88 \mathrm{a}$ \\
\hline $\mathrm{B} \times 5 \%$ & $52.00 \mathrm{c}$ & $35.0 \mathrm{efg}$ & $4.00 \mathrm{e}$ & $1.70 \mathrm{f}$ \\
\hline BK $\times 5 \%$ & $63.00 \mathrm{~b}$ & $27.0 \mathrm{ghi}$ & $4.83 \mathrm{~d}$ & $2.45 \mathrm{e}$ \\
\hline $\mathrm{KB} \times 5 \%$ & $31.00 \mathrm{~d}$ & $53.0 \mathrm{~cd}$ & $3.93 \mathrm{e}$ & $1.80 \mathrm{f}$ \\
\hline $\mathrm{K} \times 5 \%$ & $20.00 \mathrm{e}$ & $62.0 \mathrm{abc}$ & $3.13 \mathrm{f}$ & $0.13 \mathrm{~g}$ \\
\hline UK x $5 \%$ & $64.00 \mathrm{~b}$ & 26.0 ghi & $5.63 \mathrm{c}$ & $3.13 \mathrm{~d}$ \\
\hline $\mathrm{B} \times 10 \%$ & $0.00 \mathrm{f}$ & $26.0 \mathrm{ghi}$ & $0.35 \mathrm{i}$ & $0.05 \mathrm{~g}$ \\
\hline BK $\times 10 \%$ & $0.00 \mathrm{f}$ & $75.0 \mathrm{a}$ & $2.10 \mathrm{~g}$ & $0.30 \mathrm{~g}$ \\
\hline $\mathrm{KB} \times 10 \%$ & $0.00 \mathrm{f}$ & 20.0 ghij & $0.23 \mathrm{i}$ & $0.00 \mathrm{~g}$ \\
\hline $\mathrm{K} \times 10 \%$ & $0.00 \mathrm{f}$ & $45.0 \mathrm{def}$ & $0.53 \mathrm{i}$ & $0.03 \mathrm{~g}$ \\
\hline UK x $10 \%$ & $0.00 \mathrm{f}$ & $68.0 \mathrm{ab}$ & $1.45 \mathrm{~h}$ & $0.10 \mathrm{~g}$ \\
\hline $\mathrm{B} \times 15 \%$ & $0.00 \mathrm{f}$ & $3.0 \mathrm{kl}$ & $0.00 \mathrm{i}$ & $0.00 \mathrm{~g}$ \\
\hline $\mathrm{BK} \times 15 \%$ & $0.00 \mathrm{f}$ & $54.0 \mathrm{bcd}$ & $0.00 \mathrm{i}$ & $0.00 \mathrm{~g}$ \\
\hline $\mathrm{KB} \times 15 \%$ & $0.00 \mathrm{f}$ & 1.01 & $0.00 \mathrm{i}$ & $0.00 \mathrm{~g}$ \\
\hline $\mathrm{KB} \times 15 \%$ & $0.00 \mathrm{f}$ & 18.0 hijk & $0.00 \mathrm{i}$ & $0.00 \mathrm{~g}$ \\
\hline UK x $15 \%$ & $0.00 \mathrm{f}$ & $62.0 \mathrm{abc}$ & $0.30 \mathrm{i}$ & $0.00 \mathrm{~g}$ \\
\hline B $\times 20 \%$ & $0.00 \mathrm{f}$ & 0.01 & $0.00 \mathrm{i}$ & $0.00 \mathrm{~g}$ \\
\hline $\mathrm{BK} \times 20 \%$ & $0.00 \mathrm{f}$ & $32.0 \mathrm{fgh}$ & $0.00 \mathrm{i}$ & $0.00 \mathrm{~g}$ \\
\hline $\mathrm{KB} \times 20 \%$ & $0.00 \mathrm{f}$ & 0.01 & $0.00 \mathrm{i}$ & $0.00 \mathrm{~g}$ \\
\hline $\mathrm{K} \times 20 \%$ & $0.00 \mathrm{f}$ & $13.0 \mathrm{ijkl}$ & $0.00 \mathrm{i}$ & $0.00 \mathrm{~g}$ \\
\hline UK x $20 \%$ & $0.00 \mathrm{f}$ & $49.0 \mathrm{cde}$ & $0.00 \mathrm{i}$ & $0.00 \mathrm{~g}$ \\
\hline $\mathrm{B} \times 25 \%$ & $0.00 \mathrm{f}$ & 0.01 & $0.00 \mathrm{i}$ & $0.00 \mathrm{~g}$ \\
\hline BK $\times 25 \%$ & $0.00 \mathrm{f}$ & $8.0 \mathrm{jkl}$ & $0.00 \mathrm{i}$ & $0.00 \mathrm{~g}$ \\
\hline $\mathrm{KB} \times 25 \%$ & $0.00 \mathrm{f}$ & 0.01 & $0.00 \mathrm{i}$ & $0.00 \mathrm{~g}$ \\
\hline $\mathrm{K} \times 25 \%$ & $0.00 \mathrm{f}$ & $3.0 \mathrm{kl}$ & $0.00 \mathrm{i}$ & $0.00 \mathrm{~g}$ \\
\hline UK x $25 \%$ & $0.00 \mathrm{f}$ & $24.0 \mathrm{ghi}$ & $0.00 \mathrm{i}$ & $0.00 \mathrm{~g}$ \\
\hline $\begin{array}{l}\text { Prob. F > 5 } \\
\%\end{array}$ & 0.0001 & 0.0001 & 0.0001 & 0.0001 \\
\hline \multicolumn{5}{|c|}{$\begin{array}{l}\mathrm{K}=\text { dry irrigation pattern swampland; } \mathrm{UK}=\text { Ultisol soil with dry } \\
\text { irrigation pattern; } \mathrm{B}=\text { wet irrigation pattern swampland; } \mathrm{BK}=\text { wet- } \\
\text { dry irrigation pattern swampland; } \mathrm{KB}=\text { wet-dry irrigation pattern } \\
\text { swampland. The numbers in the same column followed by the } \\
\text { same letters are not significantly different in the Duncan test at the } \\
5 \% \text { level. }\end{array}$} \\
\hline
\end{tabular}

alternative in producing bioherbicides. However, there is a weakness in swamplands with dry irrigation patterns, namely that the resulting biomass is lower (due to drought stress) compared to other treatments. The resulting normal sprout pattern was low, 
indicating that the seeds could not carry out metabolic activities in the sprout process properly. This shows that there is a role for allelopathy in sorghum water extract in inhibiting the sprout process it receives.

In Table 2, the interaction of extract concentration and irrigation patterns has a significant effect on the observed variables. The interaction of irrigation patterns of dry ultisol soil and dry wet swamp soil with a concentration of $10 \%$ resulted in $68 \%$ and $75 \%$ abnormal sprouts, respectively. All irrigation patterns achieved the lowest interaction to produce abnormal sprouts with an extract concentration of $0 \%$ (control treatment). This indicated that the $0 \%$ concentration of sorghum extract did not inhibit the sprouts because the bioassay media did not contain any allelochemical

compounds. Basically, the water extract which is getting higher, the higher the abnormal sprouts (the highest concentration was between $5 \%-10 \%$ in the dry irrigation pattern, wet dry on swampy soils, and dry on Ultisol soil). This shows that the irrigation pattern to produce the highest plumule inhibition can be achieved by applying a water extract of $10 \%$ to $5 \%$ of the cultivation yield in swamps and ultisols with a dry irrigation pattern. Sorghum water extract contains allelochemical compounds that can affect plant growth and development. Allelochemical is a derivative of secondary metabolites and affects the growth and development of the roots of the recipient plant. The interaction effect between the concentration of sorghum water extract and the irrigation pattern had a significant effect on plumule length (Table 2).

The lowest plumule length resulted from all irrigation patterns at a water extract concentration of $0 \%$ (without treatment). This means that there is an interaction of sorghum water extract with the irrigation pattern at a certain concentration of $0 \%$ does not contain an inhibiting compound in the bioassay media, so that it does not have an inhibitory power against the tested plants in this experiment. The interaction between the water extract concentration of $5 \%$ and the dry irrigation pattern in swamp land resulted in the lowest plumule length $(3.13 \mathrm{~cm})$. This means that the dry stress in sorghum (as a water extraction material) at a water extract concentration of $5 \%$ produces the highest inhibition power. The radicle length variable showed a significant interaction effect between the irrigation pattern and the sorghum extract concentration as shown in Table 2. Basically all irrigation
Table 3. Effect of interactions between the concentration of sorghum water extract and irrigation patterns on several experimental variables

\begin{tabular}{|c|c|c|c|c|c|}
\hline Treatment & $\begin{array}{l}\text { Plumula } \\
\text { wet } \\
\text { weight } \\
\text { (g) }\end{array}$ & $\begin{array}{l}\text { Radicle } \\
\text { wet } \\
\text { weight } \\
\text { (g) }\end{array}$ & $\begin{array}{c}\text { Wet } \\
\text { weight } \\
\text { of } \\
\text { cotyledon } \\
\text { (g) }\end{array}$ & $\begin{array}{l}\text { Plumula } \\
\text { dry } \\
\text { weight } \\
\text { (g) }\end{array}$ & $\begin{array}{l}\text { Radicle } \\
\text { dry } \\
\text { weight } \\
\text { (g) }\end{array}$ \\
\hline \multicolumn{6}{|c|}{ Irrigation patterns (I) } \\
\hline $\bar{B}$ & $0.0180 \mathrm{~b}$ & $0.0044 \mathrm{a}$ & $0.0444 \mathrm{a}$ & $0.0016 \mathrm{c}$ & $0.00041 \mathrm{c}$ \\
\hline BK & $0.0202 \mathrm{~b}$ & $0.0044 \mathrm{a}$ & $0.0432 \mathrm{ab}$ & $0.0022 \mathrm{a}$ & $0.00049 \mathrm{~b}$ \\
\hline $\mathrm{KB}$ & $0.0190 \mathrm{~b}$ & $0.0039 \mathrm{a}$ & $0.0422 \mathrm{~b}$ & $0.0019 \mathrm{~b}$ & $0.00045 \mathrm{bc}$ \\
\hline $\mathrm{K}$ & $0.0186 \mathrm{~b}$ & $0.0039 \mathrm{a}$ & $0.0443 \mathrm{a}$ & $0.0019 \mathrm{~b}$ & $0.00033 \mathrm{~d}$ \\
\hline UK & $0.0227 \mathrm{a}$ & $0.0045 \mathrm{a}$ & $0.0399 \mathrm{c}$ & $0.0024 \mathrm{a}$ & $0.00057 \mathrm{a}$ \\
\hline $\begin{array}{l}\text { Prob. F> } 5 \\
\%\end{array}$ & 0.0006 & 0.5854 & 0.0001 & 0.0001 & 0.0001 \\
\hline \multicolumn{6}{|c|}{ Extract concentation (E) } \\
\hline $0 \%$ & $0.0689 \mathrm{a}$ & $0.0190 \mathrm{a}$ & $0.0351 \mathrm{~d}$ & $0.0063 \mathrm{a}$ & $0.00194 \mathrm{a}$ \\
\hline $5 \%$ & $0.0402 \mathrm{~b}$ & $0.0056 \mathrm{~b}$ & $0.0419 \mathrm{c}$ & $0.0043 \mathrm{~b}$ & $0.00073 \mathrm{~b}$ \\
\hline $10 \%$ & $0.0088 \mathrm{c}$ & $0.0006 \mathrm{c}$ & $0.0452 \mathrm{a}$ & $0.0012 \mathrm{~d}$ & $0.00006 \mathrm{c}$ \\
\hline $15 \%$ & $0.0007 \mathrm{~d}$ & $0.0000 \mathrm{c}$ & $0.0465 \mathrm{a}$ & $0.0001 \mathrm{~d}$ & $0.00000 \mathrm{c}$ \\
\hline $20 \%$ & $0.0000 \mathrm{~d}$ & $0.0000 \mathrm{c}$ & $0.0448 \mathrm{ab}$ & $0.0000 \mathrm{~d}$ & $0.00000 \mathrm{c}$ \\
\hline $25 \%$ & $0.0000 \mathrm{~d}$ & $0.0000 \mathrm{c}$ & $0.0432 \mathrm{bc}$ & $0.0000 \mathrm{~d}$ & $0.00000 \mathrm{c}$ \\
\hline $\begin{array}{l}\text { Prob. F> } 5 \\
\%\end{array}$ & 0.0001 & 0.0001 & 0.0001 & 0.0001 & 0.0001 \\
\hline \multicolumn{6}{|c|}{ Interaction I x E } \\
\hline $\mathrm{B} \times 0 \%$ & $0.0696 \mathrm{a}$ & $0.0190 \mathrm{ab}$ & 0.0386 ghij & $0.0060 \mathrm{c}$ & $0.0019 \mathrm{bc}$ \\
\hline $\mathrm{BK} \times 0 \%$ & $0.0603 \mathrm{~b}$ & $0.0171 \mathrm{~b}$ & $0.0345 \mathrm{ijk}$ & $0.0062 \mathrm{bc}$ & $0.0018 \mathrm{c}$ \\
\hline $\mathrm{KB} \times 0 \%$ & $0.0735 \mathrm{a}$ & $0.0196 \mathrm{ab}$ & $0.0357 \mathrm{ijk}$ & $0.0069 \mathrm{a}$ & $0.0020 \mathrm{ab}$ \\
\hline $\mathrm{K} \times 0 \%$ & $0.0729 \mathrm{a}$ & $0.0215 \mathrm{a}$ & $0.0336 \mathrm{k}$ & $0.0066 \mathrm{ab}$ & $0.0019 b c$ \\
\hline UK x $0 \%$ & $0.0681 \mathrm{a}$ & $0.0179 \mathrm{~b}$ & $0.0342 \mathrm{jk}$ & $0.0061 \mathrm{c}$ & $0.0021 \mathrm{a}$ \\
\hline B $\times 5 \%$ & 0.0369 ef & $0.0057 \mathrm{de}$ & 0.0439 def & $0.0034 \mathrm{f}$ & $0.0006 \mathrm{f}$ \\
\hline BK $\times 5 \%$ & $0.0442 \mathrm{~d}$ & $0.0081 \mathrm{~cd}$ & $0.0453 \mathrm{cde}$ & $0.0048 \mathrm{~d}$ & $0.0011 \mathrm{e}$ \\
\hline $\mathrm{KB} \times 5 \%$ & $0.0381 \mathrm{e}$ & $0.0037 \mathrm{ef}$ & 0.0390 fghi & $0.0042 \mathrm{e}$ & $0.0007 \mathrm{f}$ \\
\hline $\mathrm{K} \times 5 \%$ & $0.0322 \mathrm{f}$ & $0.0015 \mathrm{fg}$ & 0.0435 defg & 0.0038 ef & $0.0001 \mathrm{~g}$ \\
\hline UK $\times 5 \%$ & $0.0496 \mathrm{c}$ & $0.0090 \mathrm{c}$ & 0.0379 hijk & $0.0053 \mathrm{~d}$ & $0.0013 \mathrm{~d}$ \\
\hline $\mathrm{B} \times 10 \%$ & $0.0040 \mathrm{~h}$ & $0.0015 \mathrm{fg}$ & $0.0463 \mathrm{bcd}$ & 0.0005 hij & $0.0000 \mathrm{~g}$ \\
\hline $\mathrm{BK} \times 10 \%$ & $0.0167 \mathrm{~g}$ & $0.0010 \mathrm{fg}$ & $0.0434 \mathrm{defgh}$ & $0.0022 \mathrm{~g}$ & $0.0002 \mathrm{~g}$ \\
\hline $\mathrm{KB} \times 10 \%$ & $0.0021 \mathrm{~h}$ & $0.0000 \mathrm{~g}$ & $0.0447 \mathrm{cde}$ & $0.0003 \mathrm{ij}$ & $0.0000 \mathrm{~g}$ \\
\hline $\mathrm{K} \times 10 \%$ & $0.0062 \mathrm{~h}$ & $0.0002 \mathrm{~g}$ & $0.0510 \mathrm{a}$ & $0.0009 \mathrm{~h}$ & $0.0000 \mathrm{~g}$ \\
\hline UK $\times 10 \%$ & $0.0149 \mathrm{~g}$ & $0.0003 \mathrm{~g}$ & 0.0419 defgh & $0.0022 \mathrm{~g}$ & $0.0001 \mathrm{~g}$ \\
\hline B $\times 15 \%$ & $0.0000 \mathrm{~h}$ & $0.0000 \mathrm{~g}$ & 0.0462 bcde & $0.0000 \mathrm{j}$ & $0.0000 \mathrm{~g}$ \\
\hline $\mathrm{BK} \times 15 \%$ & $0.0000 \mathrm{~h}$ & $0.0000 \mathrm{~g}$ & $0.0495 \mathrm{abc}$ & $0.0000 \mathrm{j}$ & $0.0000 \mathrm{~g}$ \\
\hline $\mathrm{KB} \times 15 \%$ & $0.0000 \mathrm{~h}$ & $0.0000 \mathrm{~g}$ & 0.0450 cde & $0.0000 \mathrm{j}$ & $0.0000 \mathrm{~g}$ \\
\hline $\mathrm{KB} \times 15 \%$ & $0.0000 \mathrm{~h}$ & $0.0000 \mathrm{~g}$ & $0.0508 \mathrm{ab}$ & $0.0000 \mathrm{j}$ & $0.0000 \mathrm{~g}$ \\
\hline UK $\times 15 \%$ & $0.0036 \mathrm{~h}$ & $0.0000 \mathrm{~g}$ & 0.0411 efgh & $0.0006 \mathrm{hi}$ & $0.0000 \mathrm{~g}$ \\
\hline $\mathrm{B} \times 20 \%$ & $0.0000 \mathrm{~h}$ & $0.0000 \mathrm{~g}$ & 0.0462 bcde & $0.0000 \mathrm{j}$ & $0.0000 \mathrm{~g}$ \\
\hline BK x $20 \%$ & $0.0000 \mathrm{~h}$ & $0.0000 \mathrm{~g}$ & $0.0456 \mathrm{cde}$ & $0.0000 \mathrm{j}$ & $0.0000 \mathrm{~g}$ \\
\hline $\mathrm{KB} \times 20 \%$ & $0.0000 \mathrm{~h}$ & $0.0000 \mathrm{~g}$ & $0.0457 \mathrm{cde}$ & $0.0000 \mathrm{j}$ & $0.0000 \mathrm{~g}$ \\
\hline $\mathrm{K} \times 20 \%$ & $0.0000 \mathrm{~h}$ & $0.0000 \mathrm{~g}$ & $0.0444 \mathrm{de}$ & $0.0000 \mathrm{j}$ & $0.0000 \mathrm{~g}$ \\
\hline UK x $20 \%$ & $0.0000 \mathrm{~h}$ & $0.0000 \mathrm{~g}$ & $0.0423 \mathrm{defgh}$ & $0.0000 \mathrm{j}$ & $0.0000 \mathrm{~g}$ \\
\hline B $\times 25 \%$ & $0.0000 \mathrm{~h}$ & $0.0000 \mathrm{~g}$ & 0.0451 cde & $0.0000 \mathrm{j}$ & $0.0000 \mathrm{~g}$ \\
\hline BK x $25 \%$ & $0.0000 \mathrm{~h}$ & $0.0000 \mathrm{~g}$ & 0.0421 defgh & $0.0000 \mathrm{j}$ & $0.0000 \mathrm{~g}$ \\
\hline $\mathrm{KB} \times 25 \%$ & $0.0000 \mathrm{~h}$ & $0.0000 \mathrm{~g}$ & $0.0441 \mathrm{de}$ & $0.0000 \mathrm{j}$ & $0.0000 \mathrm{~g}$ \\
\hline $\mathrm{K} \times 25 \%$ & $0.0000 \mathrm{~h}$ & $0.0000 \mathrm{~g}$ & 0.0427 defgh & $0.0000 \mathrm{j}$ & $0.0000 \mathrm{~g}$ \\
\hline UK x $25 \%$ & $0.0000 \mathrm{~h}$ & $0.0000 \mathrm{~g}$ & 0.0421 defgh & $0.0000 \mathrm{j}$ & $0.0000 \mathrm{~g}$ \\
\hline $\begin{array}{l}\text { Prob. F> } 5 \\
\%\end{array}$ & 0.0001 & 0.0003 & 0.0025 & 0.0001 & 0.0001 \\
\hline
\end{tabular}

$\mathrm{K}=$ dry irrigation pattern swampland; UK = Ultisol soil with dry irrigation pattern; $\mathrm{B}=$ wet irrigation pattern swampland; $\mathrm{BK}=$ wetdry irrigation pattern swampland; $\mathrm{KB}=$ wet-dry irrigation pattern swampland. The numbers in the same column followed by the same letters are not significantly different in the Duncan test at the $5 \%$ level.

patterns with a water extract concentration of $0 \%$ (without treatment) produced the highest radicle length. This means that the interaction effect of all irrigation patterns with a water extract concentration of $0 \%$ (without treatment) has no inhibitory power against the plants tested in this experiment. The interaction effect of dry irrigation patterns in swamps with a water extract concentration of $5.0 \%$ resulted in 
the lowest radicle length of $0.13 \mathrm{~cm}$. This shows that the drought stress of sorghum in swamps at a water extract concentration of $5.0 \%$ resulted in the highest inhibition of germination. The higher the concentration of sorghum aqueous extract, the more stressed the length of the radicle will be. Dry irrigation patterns in marshlands make the shortest radicle lengths. When compared between the variable length of the radicle and size of the plumule to the reduction in plumule length and radicle length from low to the high concentration of extracts, it was shown that the highest reduction in length was experienced by the length of the radicle. This means that the radicle component is more sensitive to sorghum extract because the planting medium is in direct contact with the radicle organs. The root component in sorghum plants has the highest sorgoleon content which can inhibit the growth of the test plant, especially in the root or radicle component. According to [5], the well-known phytotoxicity of sorghum root exudates is sorgoleon, but phenolic acid also has a role. In the future, sorghum is an environmentally friendly weed controller.

The wet weight variable of plumula was significantly influenced by the interaction between the irrigation pattern and the water extract concentration as shown in Table 3. In the dry irrigation pattern in swamps with a concentration of $5.0 \%$, the smallest wet weight was $0.0322 \mathrm{~g}$. However, this is not much different from the wet irrigation pattern in swamps. This implies that the interaction of dry irrigation patterns in swamps with a water extract concentration of $5.0 \%$ results in drought stress and has an impact on the highest allelopathy accumulation so that it plays a role in inhibiting the wet weight of plumule feathers.

The interaction between the irrigation pattern and the water extract concentration significantly affected the wet weight of the radicle shown in Table 3 . The dry irrigation pattern in swamps with a water extract concentration of $5.0 \%$ resulted in the lowest wet weight of the radicle, namely $0.0015 \mathrm{~g}$. However, this was not significantly different from the interaction on wet-dry patterns in swamps and all irrigation patterns were concentrated at $10.0 \%$.

This means that the interaction of dry irrigation patterns in swamplands at a concentration of $5.0 \%$ has an impact in the form of the highest drought stress so that it will produce the highest inhibition power. According to (5) biotic and abiotic factors determine the effect of allelopathy, and the allelopathic approach is an environmentally friendly method. In general, the higher the concentration of sorghum aqueous extract given to the bioassay media, the lower the wet weight of the radicle. Radicles are more depressed than plumules, this can be seen in the value of these two variables.

The interaction between the irrigation pattern and the concentration of sorghum water extract had a significant effect on the wet weight of cotyledons as shown in Table 3. The dry irrigation pattern in swamps at a concentration of $10.0 \%$ resulted in the largest wet weight of cotyledons, namely $0.0510 \mathrm{~g}$. This shows a significant difference when compared with other interactions (especially at a concentration of $10 \%)$. This means that the interaction of dry irrigation patterns in swamplands with a sorghum water extract concentration of $10 \%$ results in the highest stress and has an impact on the inhibition of cotyledons in the germination process.

The interaction between irrigation pattern and water extract concentration had a significant effect on cotyledon wet weight (Table 3). The dry irrigation pattern in swamp land at a water extract concentration of $10.0 \%$ resulted in the largest wet weight of cotyledons, namely $0.0510 \mathrm{~g}$. This shows something different from other interactions (especially at a concentration of $10.0 \%$ ). This means that the interaction of dry irrigation patterns in swamplands with a water extract concentration of $10.0 \%$ results in the highest stress and this will result in decreased cotyledons in the germination process. The condition of the cotyledons that is inhibited by water extract in the form of allelopathy results in the inability to carry out the normal metabolic activity of sprouts, resulting in high wet weight of the cotyledons.

The interaction between the irrigation pattern and the concentration of sorghum water extract had a significant effect on plumule dry weight as shown in Table 3. The dry irrigation pattern in swamplands with a water extract concentration of $5.0 \%$ resulted in the lowest plumule dry weight of $0.0038 \mathrm{~g}$. However, this was not significantly different from the wet irrigation pattern $(0.034 \mathrm{~g})$. This implies that the interaction of dry irrigation patterns in swamplands at a water extract concentration of $5.0 \%$ has an impact on drought stress which results in high allelopathic content so that it has an impact on decreasing the dry weight of the resulting plumules.

The interaction effect between the water extract concentration of sorghum and the irrigation pattern had a significant effect on the dry weight of the radicle produced as shown in Table 3 . The dry irrigation pattern model in swamp land with a sorghum water extract concentration of $5.0 \%$ resulted 
in the smallest radicle dry weight of $0.0001 \mathrm{~g}$. This means that the interaction between the water extract concentration of $5.0 \%$ and the dry irrigation pattern results in drought stress which affects radicle suppression. Basically, the higher the concentration of sorghum water extract given to the bioassay media, the smaller the dry weight of the radicles produced. The dry weight of the radicles is more depressed than the dry weight of the plumules. This is because the radicle is in direct contact with the bioassay media in this experiment so that it has an impact on germination growth. Root organs are more sensitive than canopy organs. Root organs are more susceptible to the effects of allelopathy than canopy organs. Allelochemical inhibits the form of suppressing the growth of roots or radicles, thereby significantly reducing meristem activity and root cell length.

As shown in Table 4, the irrigation pattern significantly affected the dry weight of the cotyledons. The largest cotyledon dry weight was achieved by the irrigation pattern applied in swamp land. This means that all irrigation patterns used in swamp land can produce the highest allelopathy when compared to Ultisol soils, so that this will have an impact on inhibition of sprouts.

Table 4. An average dry weight of cotyledons

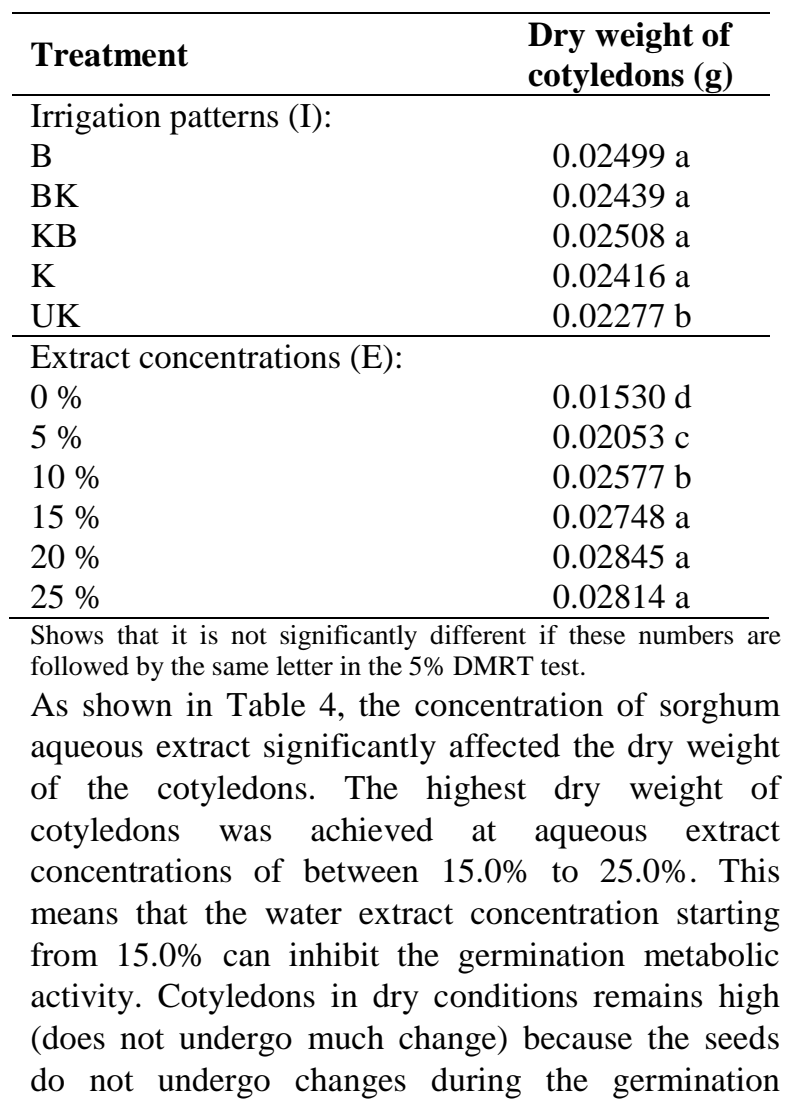

process. According to [14] the water extract concentration of $7.50 \%$ sorghum in dry irrigation in ultisols and swamp dry soils was able to inhibit the highest sorghum seed germination. Sorghum cultivated in swampy soils or Ultisols with a dry irrigation pattern can produce high allelopathy.

\section{CONCLUSION}

The strategy to produce high allelopathy can be developed in sorghum cultivation in swamps with dry irrigation patterns. The dry irrigation pattern in swamps with a water extract concentration of 5\% $10 \%$ sorghum resulted in the highest inhibition of sorghum germination. Sorghum water extract produced from cultivation in swamps, especially in dry conditions, will produce a good bioherbicide.

\section{REFERENCES}

[1] A. M. Tubeileh, R.T. Souikane, Effect of olive vegetation water and compost extracts on seed sprout of four weed species, Current Plant Biology 22(March) 2020 100-150. DOI: https://doi.org/10.1016/j.cpb.2020.100150

[2] M. Arif, Z.A. Cheema, A. Khaliq, A. Hassan, Organic weed management in wheat through allelopathy, International Journal of Agriculture and Biology 17(1) 2015 127-34.

[3] I.S. Alsaadawi, T.A. Al-Khateeb, H.A. Hadwan, N.R. Lahmood, A chemical basis for differential allelopathic potential of root exudates of Sorghum bicolor L. (Moench) cultivars on companion weeds, Journal of Allelochemical Interactions 11 (2015) 49-55.

[4] S. Hussain, F. Hassan, M. Rasheed, S. Ali, M. Ahmed, Effects of allelopathic crop water extracts and their combinations on weeds and yield of rainfed wheat, Journal of Food, Agriculture and Environment 12(3-4) (2014) 161-67.

[5] M. Ashraf, M. Akhlaq, Effects of sorghum leaves, roots and stems water extract, hand weeding and herbicide on weeds suppression and yield of wheat, Sarhad Journal of Agriculture 23(2) (2007) 321-27.

[6] Y. Nornasuha, B.S. Ismail, Sustainable weed management using allelopathic approach, Malaysian Applied Biology 46 (2) (2017) 1-10.

[7] N.B. Appiah-Nkansah, J. Li, W. Rooney, D. Wang, A review of sweet sorghum as a viable 
renewable bioenergy crop and its technoeconomic analysis, Renewable Energy 143 (2019) 112-132. DOI: https://doi.org/10.1016/j.renene.2019.05.066

[8] M.J.W. Maw, J.H. Houx, F.B. Fritschi, Sweet sorghum ethanol yield component response to nitrogen fertilization, Industrial Crops and Products 84 (2016) 43-49. DOI: https://doi.org/10.1016/j.indcrop.2016.01.038

[9] M.J.W. Maw, J.H. Houx, F.B. Fritschi, Maize, sweet sorghum, and high biomass sorghum ethanol yield comparison on marginal soils in Midwest USA, Biomass and Bioenergy 107(March) (2017) 164-71. DOI: https://doi.org/10.1016/j.biombioe.2017.09.021

[10] M. Kandhro, H-R. Memon, M. Laghari, A. Baloch, M. Ansari, Allelopathic Impact of Sorghum and Sunflower on Germinability and Seedling Growth of Cotton (Gossypium hirsutum L.), Journal of Basic \& Applied Sciences 12 (2016) 98-102. DOI: https://doi.org/10.6000/1927-5129.2016.12.15

[11] S. Siyar, A. Majeed, Z. Muhammad, H. Ali, N. Inayat, Allelopathic effect of aqueous extracts of three weed species on the growth and leaf chlorophyll content of bread wheat, Acta Ecologica Sinica 39(1) (2019) 63-68. DOI: https://doi.org/10.1016/j.chnaes.2018.05.007

[12] C-Z. Huang, L. Xu, S. Jin-jing, Z-H. Zhang, ML Fu, H-Y. Teng, K-K. YI, Allelochemical phydroxybenzoic' acid inhibits root growth via regulating ROS accumulation in cucumber (Cucumis sativus L.), Journal of Integrative Agriculture 19(2) (2020) 518-527. DOI: https://doi.org/10.1016/S2095-3119(19)62781-4

[13] M. Wakjira, G. Berecha, S. Tulu, Allelopathic effects of an invasive alien weed Parthenium hysterophorus L. compost on lettuce sprout and growth, African Journal of Agricultural Research 4 (11) (2009) 1325-1330.

[14] E. Susilo, N. Setyowati, U. Nurjanah, Riwandi, Z. Muktamar, Sorghum Germination Inhibition Using Its Water Extract Cultivated in Swampland with Different Irrigation Patterns. IOP Conference Series: Earth and Environmental Science 694(1) (2021) 012-027 DOI: $\quad$ https://doi.org/10.1088/1755$\underline{1315 / 694 / 1 / 012027}$ 